\title{
The shelf-edge current north-west of Ireland
}

\author{
M. White, P. Bowyer \\ Department of Oceanography, Martin Ryan Marine Science Institute, University College, Galway, Ireland
}

Received: 3 September 1996 / Revised: 17 February 1997 / Accepted: 24 February 1997

\begin{abstract}
Measurements of the slope current at two locations north-west of Ireland have been made between April and December 1994, $40 \mathrm{~m}$ above the seabed in a water depth of $660 \mathrm{~m}$. A persistent poleward alongslope current was observed at both locations, with measured means of 10 and $21 \mathrm{~cm} \mathrm{~s}^{-1}$ respectively. A CTD transect across the slope near one mooring indicated the presence of a light, warm, saline core of water at the shelf edge. Peak currents were $O(50) \mathrm{cm} \mathrm{s}^{-1}$, with strongest mean flow at the location with steeper slope. Variability at sub-tidal periods, principally 2-5 and 11-12 days, was apparent. The shorter-period variability was well correlated with coastal sea-level variations measured at a land point near to one of the moorings. The variability in the slope current at this period appeared to be a result of the warm current core movement up/down slope, probably as a result of interaction with higher-mode shelf waves. Some suggestion of a bottom-trapped diurnal wave was also found at one location.
\end{abstract}

\section{Introduction}

A polewards-flowing current is known to exist along most, if not all, of the North-east Atlantic margin, extending northwards from the Iberian margin to the Norwegian Sea (Pingree and LeCann, 1989, 1990; Huthnance and Gould, 1989). This shelf-edge current (SEC) plays an important role in physical exchange processes at the shelf break and hence cross-shelf fluxes (Huthnance, 1995). In the Bay of Biscay/Celtic Sea region, mean northward velocities of $O(5-10) \mathrm{cm} \mathrm{s}^{-1}$ have been measured with a volume transport, estimated between the shelf break and the $1000-\mathrm{m}$ isobath at

Correspondence to: M. White $47.5^{\circ} \mathrm{N}$, of $O(0.6 \mathrm{~Sv})$ (Pingree and LeCann, 1989). A southward counter flow on the Celtic Shelf has been observed, partly driven by the mean wind stress and by local density gradients.

Further north, velocities and transports are generally stronger. For example, Booth and Ellett (1983) have measured a mean current of $16 \mathrm{~cm} \mathrm{~s}^{-1}$ on the slope west of Scotland. Estimates of transport during CONSLEX were between 1.2 and $2.2 \mathrm{~Sv}$ for the slope region at $58^{\circ} \mathrm{N}$. This may be compared to the volume transport estimated for the upper $500 \mathrm{~m}$ of the deeper portion of the Rockall Trough, of 2.7-4.7 Sv (Ellett and Martin, 1973). The SEC is relatively warm and saline, as shown by CTD measurements across the Malin and Hebrides Shelf (Hill and Mitchelson-Jacob, 1993). These observations indicated that between $56-59^{\circ} \mathrm{N}$ the depth of the current core decreased by about $100 \mathrm{~m}$ per $200 \mathrm{~km}$ of northward transport.

In contrast, the shelf-edge region west of Ireland, with the exception of the deeper waters west of Porcupine Bank, has recieved little attention relative to adjacent regions. Thorpe (1987) and Thorpe et al. (1991) report year-long observations from the lower slopes of the western Porcupine Bank. Mean northward currents of $1-4 \mathrm{~cm} \mathrm{~s}^{-1}$ were measured, modulated at the 5-8-day period by slope waves which, for short times, reversed the mean drift. A mean northward current near the seabed was found at two locations on the eastern flank of the Porcupine Sea Bight by Pingree and LeCann (1989, 1990). At mid-depth, the along-slope flow weakened and reversed during early spring. Temperature and salinity transects across the Sea Bight made during the Aprils of four consecutive years have revealed a persistent intrusion of warm saline surface water through the Sea Bight onto the deeper portion of the Irish Shelf, which separates the coastal shelf from the Porcupine Bank (McMahon et al., 1995).

In this paper near-bottom currents measured at the shelf edge NW of Erris Head, Ireland, between $54.5^{\circ}$ and $55^{\circ} \mathrm{N}$ are described. These measurements were made as part of the Ocean Margin EXchange 
(OMEX) program. Mean speeds and low-frequency variability are discussed, together with a comparison with previous observations along the slope. These are the first reported measurements of sub-surface currents in this particular shelf-edge region.

\section{Study area and measurements}

Three moorings were deployed along the shelf edge, NW of Erris Head, Co. Mayo, all in a water depth between 660 and $680 \mathrm{~m}$ (Fig. 1) from the Irish trawler 'An Cappall Bán'. Due to loss through fishing activity, however, only data from the lowest Aanderaa recording current meter on two moorings, both having temperature sensors, were recovered during FS Valdivia cruise 153, part of the SEFOS (Shelf-Edge Fisheries and Oceanography Study) summer 1995 fieldwork campaign. These were both at $40 \mathrm{~m}$ above the seabed. Table 1 summarises the location, water/instrument depths and observation periods for the current meters. Data were recorded hourly from mid-April to early December 1994, but data after October for mooring SW were not reliable because, at that time, this mooring was dragged into deeper water and presumably cut. In addition to the current measurements, several CTD transects were made across the shelf region west and north-west of Ireland, using an internally recording CTD during the summer 1995 SEFOS cruises. CTD salinities were calibrated using laboratory-determined salinities from bottle samples. Meterological data was also available from an Irish Meterological Office station at Belmullet (Fig. 1), close to Erris Head, and a nearby tide gauge owned by the Department of Oceanography, University College Galway.

The Irish Shelf in this region is relatively narrow compared to that further south, which includes the Porcupine Bank, or the Malin Shelf to the north. The distance from the SW mooring to the coast is about $70 \mathrm{~km}$. At SW the bottom slope is about $4^{\circ}$ at the mooring depth, and along-slope direction is $43^{\circ}$ True, determined from a chart of Seabeam echo sounder measurements. At $72 \mathrm{~km}$ along slope at NE where isobaths are closer together, the bottom slope increases to $8^{\circ}$, and is aligned more north-south, at $16^{\circ}$ True (Table 1). In this paper along-slope currents will be taken as those along the local isobath direction, positive northwards, and denoted $v$. Across-slope currents $(u)$ will be taken as positive on-shelf, to preserve a righthanded co-ordinate system.

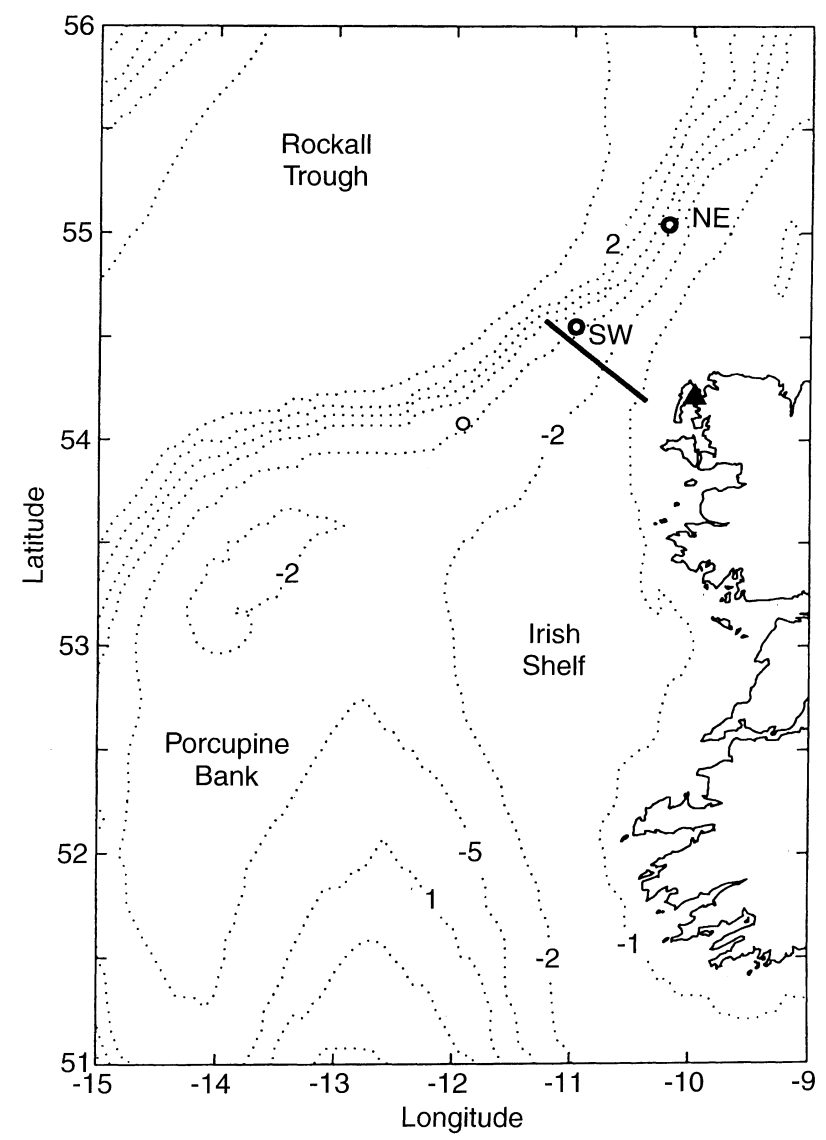

Fig. 1. Location map showing position of the two moorings (SW, $\mathrm{NE}$ ), both marked 'o', and position of a 3rd lost mooring. The filled triangle marks the position of the tide gauge and the nearby Irish Meteorological Station. The line indicates extent of the CTD transect. Contours are marked in $\mathrm{km}$

\section{$3 T-S$ Structure}

Figure 2 shows the distribution of relative (uncalibrated) surface salinity on the Irish Shelf measured in July 1995 from the FS Valdivia. The data is courtesy of C. Mohn, IfM, Hamburg, and illustrates several of the hydrographical features present. The Irish Shelf front was a consistent feature and was located between the 150-200-m isobath, separating coastal and oceanic waters (Huang et al., 1991). The outer limit in Fig. 2 was marked by the 35.3 salinity contour which corresponds well with the $200-\mathrm{m}$ isobath. In the Porcupine Sea Bight, surface waters were warm and saline. The 35.4 isohaline in the Sea Bight runs close to the 500-m

Table 1. Mooring locations, water/instrument depths and mean values for current meters deployed northwest of Ireland, 1994

\begin{tabular}{lllllr}
\hline mooring & location & $\begin{array}{l}\text { water and } \\
\text { CM depth }(\mathrm{m})\end{array}$ & $\begin{array}{l}\text { observation } \\
\text { period }\end{array}$ & $\begin{array}{l}\text { mean speed, } \\
\text { dir. (True) }\end{array}$ & $\begin{array}{l}\text { slope ang., } \\
\text { dir. (True) }\end{array}$ \\
\hline SW & $54^{\circ} 33.2 \mathrm{~N}$ & 668 & 13 April - & $9.9 \mathrm{~cm} \mathrm{~s}^{-1}$ & $4^{\circ}$ \\
& $10^{\circ} 58.08 \mathrm{~W}$ & 628 & 14 October & $43^{\circ}$ & $57^{\circ}$ \\
$\mathrm{NE}$ & $55^{\circ} 02.44 \mathrm{~N}$ & 655 & 14 April - & $21.5 \mathrm{~cm} \mathrm{~s}^{-1}$ & $8^{\circ}$ \\
& $10^{\circ} 11.54 \mathrm{~W}$ & 615 & 4 December & $6.5^{\circ}$ & $16^{\circ}$ \\
\hline
\end{tabular}




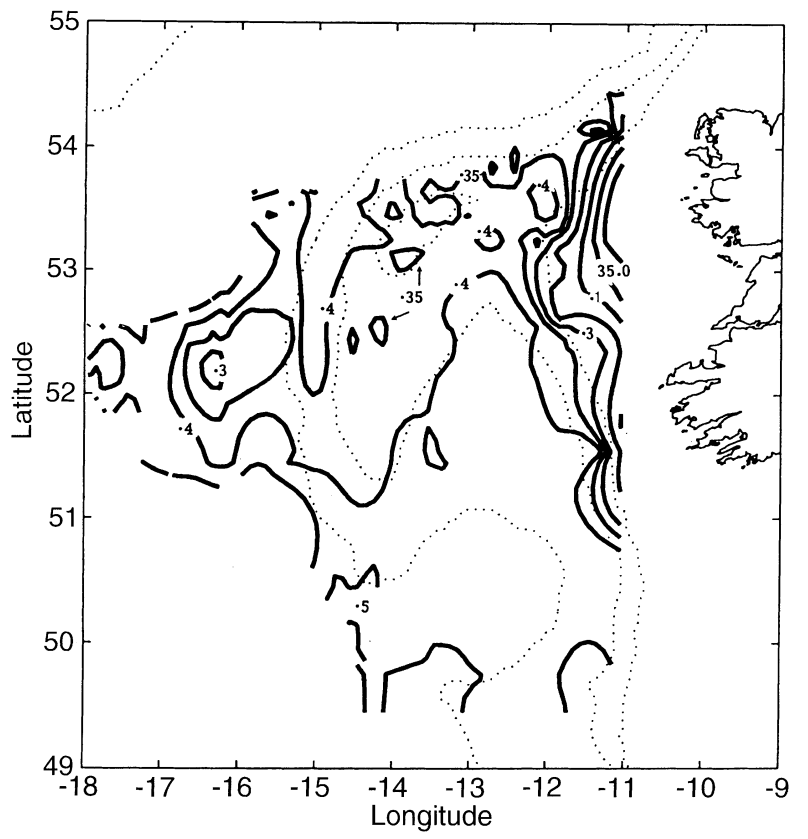

Fig. 2. Surface salinity map for July 1995. Only the 35 contour and the decimal places of other values are annotated. The contour interval is 0.1 with additionally the 35.35 contour added. The 200,500 and 2000-m isobaths are also marked by the light contour lines

isobath marking the Sea Bight region. The saline (and warmer) water extends north/north-eastwards parallel to the 200-m isobath, cutting across the deeper portion of the Irish Shelf, and this feature has been observed for several years in succession by McMahon et al. (1995). This upper-layer water has a source to the south and is probably a surface signal influenced by eastern north Atlantic water (ENAW). Pollard et al. (1996) argue that ENAW is formed through winter air-sea interaction processes and may also be partly influenced by winter mixing with Mediterranean water (MW). Surface salinities over the Porcupine Bank are about 0.05 less than surface values in deeper water either side.

Figure 3 shows the potential temperature $(\theta)$, (calibrated) salinity $(S)$ and $\sigma_{t}$ for a transect made across the shelf edge close to the SW mooring in April 1994 (Fig. 1). A light warm saline core of water was present at the shelf edge between the $300-600-\mathrm{m}$ isobaths, mixed up to the surface and also some way onto the shelf itself. This was the signature of the SEC, as previously observed along the Malin Shelf by Hill and Mitchelson-Jacob (1993), who also found the SEC core mixed in the manner found here for their winter/spring sections. Close to the coast, the Irish Shelf front was marked by strong horizontal $\theta$ and $S$ gradients. In the bottom layer beneath the front, cold dense water was observed displaced down slope. This characteristic was observed to some degree in most transects made across the Irish Shelf during spring.

Figure 4 is a $\theta-S$ diagram for the data shown in Fig. 3, where $\theta$ is the potential temperature related to the surface. The cool fresher water at the near-coast station was apparent, but all other stations fell on one
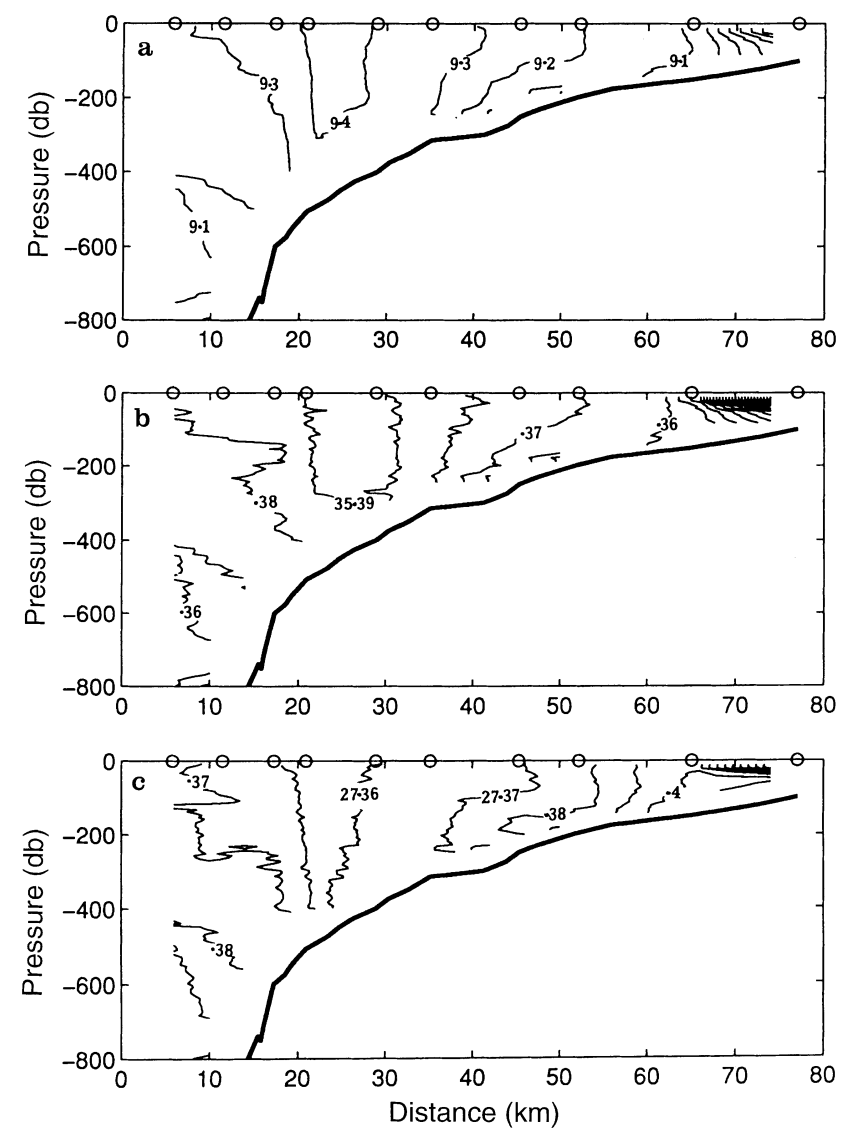

Fig. 3a-c. Vertical sections of a Potential temperature, b salinity and c $\sigma_{\theta}$, for the CTD transect shown in Fig. 1. Contour intervals are (a) $0.1^{\circ} \mathrm{C}$, (b) 0.01 and (c) $0.01 \mathrm{~kg} \mathrm{~m}^{-3}$. Station positions are indicated by the open circles

water mass line. This line was similar to the standard $\theta-S$ line for ENAW described by Harvey (1982) and Pollard et al. (1996), perhaps reflecting an influence of the surface intrusion of warmer water across the deeper portion of the Irish Shelf (Fig. 2). A large number of

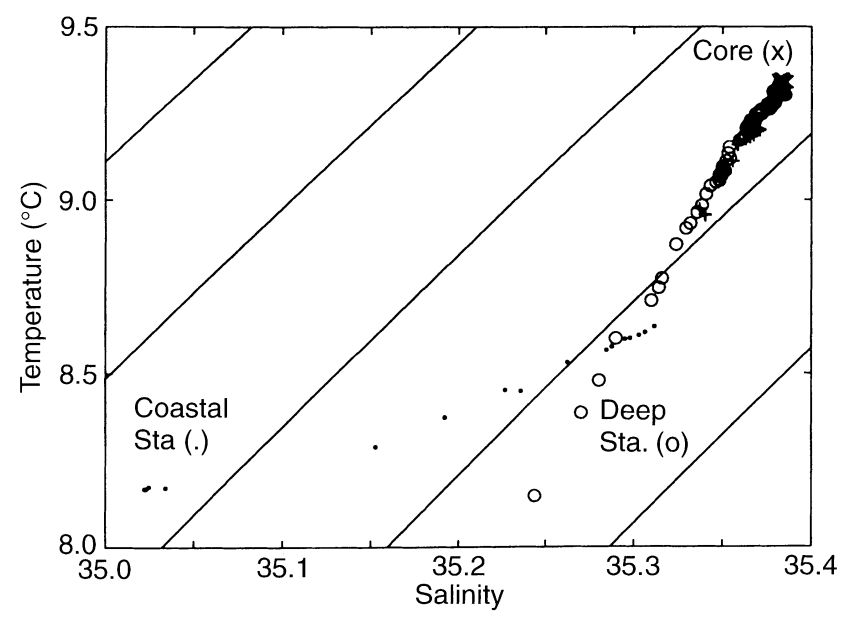

Fig. 4. Potential temperature-salinity plot for data shown in Fig. 3. Data are from (o) 2nd, (x) 5th, (+) 8th and (.) 10th station from the left as marked in Fig. 3 by the open circles 
points were clustered near $S=35.38, \theta=9.35$, marking the central core of the SEC. The diagram also indicated that the bottom coastal water was as dense as water at greater depths further off-shelf, suggesting the possibility of downslope flow of the near-bottom coastal water.

\section{Currents}

Figure 5 is a progressive vector diagram for the two current meters, using low-passed filtered data with a cut off frequency of $0.67 \mathrm{day}^{-1}(36 \mathrm{~h})$, and sub-sampled every $6 \mathrm{~h}$. Mean current speeds/directions for the observation period are noted in Table 1.

Currents were predominantly poleward, with a mean along-isobath velocity of $10 \mathrm{~cm} \mathrm{~s}^{-1}$ at $\mathrm{SW}$, increasing to $21 \mathrm{~cm} \mathrm{~s}^{-1}$ at NE. A mean off-slope component in current was also found. Low-passed filtered currents were unidirectional for the whole measurement period. This is reflected in the measured stability factor $(B)$ for the currents, determined by the ratio of mean vector velocity to mean speed for the measurement period, and expressed as a percentage. Values of $B=95 \%$ at $\mathrm{NE}$ and $B=80 \%$ at SW were found. Maximum monthly mean currents were measured in May at NE and July at SW, and early summer currents were strongest at both locations. The mean along-slope drift was also observed when an ARGOS sub-surface warning beacon broke loose from the NE mooring. Whilst it was unclear what was still attached to the drifting beacon (and hence acting as a drogue against the wind), the buoy drifted
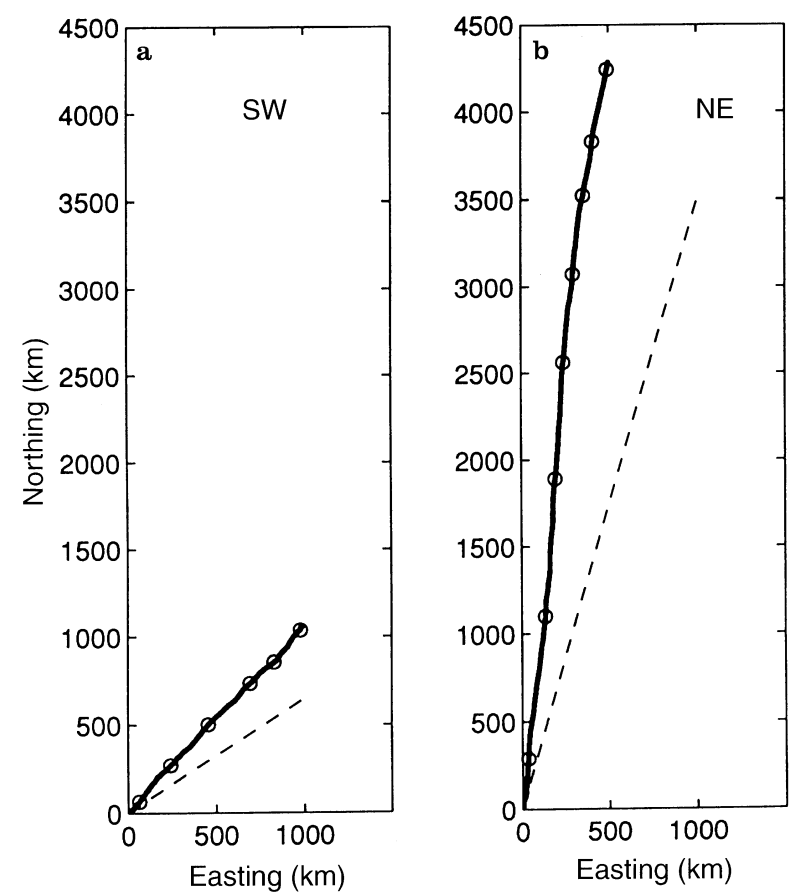

Fig. 5a, b. Progressive vector diagrams for a SW and b NE current meters. Data are filtered with a cut-off frequency of $0.67 \mathrm{cpd}$ and subsampled every $6 \mathrm{~h}$. Open circles represent the first of each month, starting from May, and the dashed line indicates the orientation of the shelf edge parallel to the isobaths with a mean velocity of $O(10) \mathrm{cm} \mathrm{s}^{-1}$, until it reached $56^{\circ} \mathrm{N}$, when the buoy crossed the shelf break onto the Malin Shelf. This was similar to the path of a buoy drogued at $66 \mathrm{~m}$ reported by Booth and Meldrum (1987), which crossed the slope onto the Malin Shelf near $55.5^{\circ} \mathrm{N}$.

Time-series of along- and across-slope currents and temperatures are shown in Fig. 6. Features observed in the vector plot were apparent in the time-series, particularly the near-continuous poleward and off-slope flow. Currents reverse southwards only briefly once at the NE mooring and four times at SW. The decrease in the $v$ component in late summer months was also apparent. Maximum velocities at NE are between 40 and $50 \mathrm{~cm} \mathrm{~s}^{-1}$, whilst at SW $v_{\max }=20 \mathrm{~cm} \mathrm{~s}^{-1}$. Maximum poleward flow was well correlated with peak off-slope currents. Warmer temperatures at SW were also partly associated at the times of peak $v$ and minimum $u$, presumably due to the movement of the SEC core downslope.

Variability at time-scales greater than the tidal periods was also apparent, particularly between 2-5 and 10-12 days at both locations. Table 2 summarises standard deviations of current time-series filtered in five different frequency bands. These bands nominally represent low-frequency ( $>10$ days), synoptic $(30 \mathrm{~h}-10$ days), diurnal $(20-30 \mathrm{~h})$, semi-diurnal $(10-20 \mathrm{~h})$ and
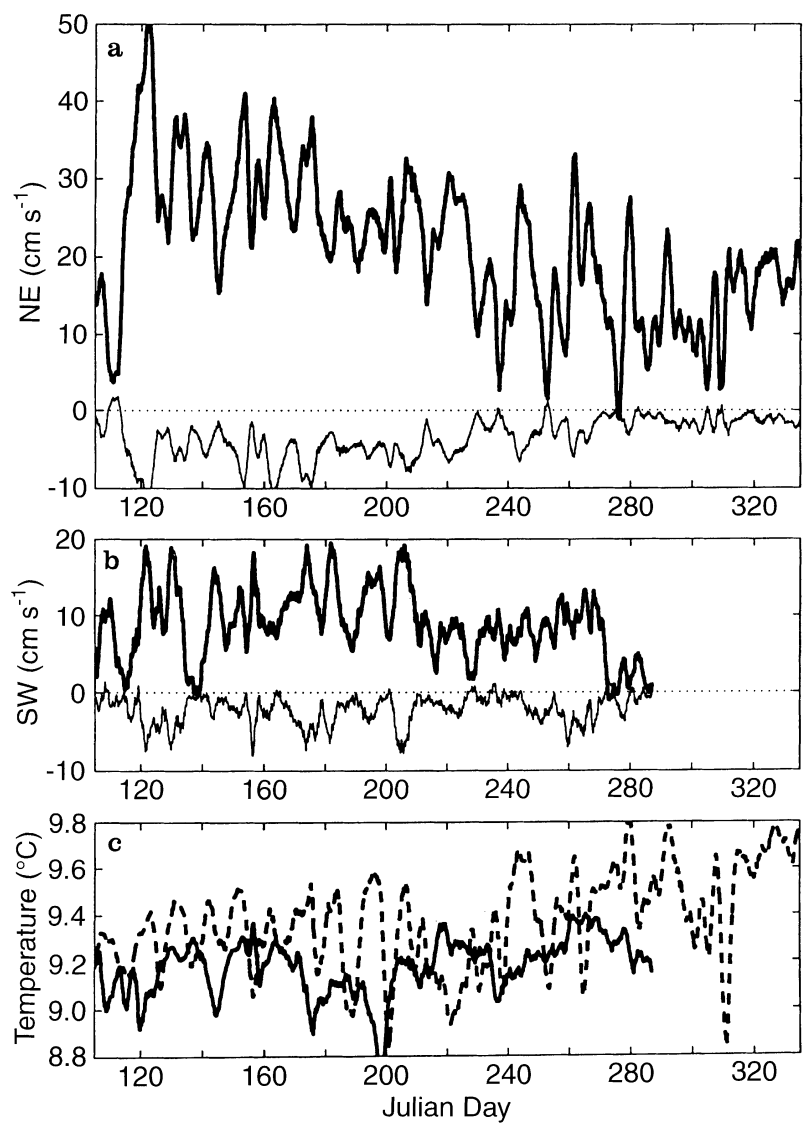

Fig. 6a-c. Time-series of (-) along-slope and (- - -) across-slope velocity at a NE, b SW and $\mathbf{c}$ temperature at (-) SW and (- - -) NE. Data have been filtered using a 50 -h running mean 
Table 2. Standard deviation of current components and temperature time-series filtered into 5 frequency bands. Current values are in $\mathrm{cm} \mathrm{s}^{-1}$ and temperatures ${ }^{\circ} \mathrm{C}$

\begin{tabular}{|c|c|c|c|c|c|}
\hline $\begin{array}{l}\text { mooring, } \\
\text { component }\end{array}$ & $\begin{array}{l}\text { low. freq. } \\
>10 \text { days }\end{array}$ & $\begin{array}{l}\text { synoptic } \\
30 \mathrm{~h}-10 \text { days }\end{array}$ & $\begin{array}{l}\text { diurnal } \\
20 \mathrm{~h}-30 \mathrm{~h}\end{array}$ & $\begin{array}{l}\text { semi-diurnal } \\
10 \mathrm{~h}-20 \mathrm{~h}\end{array}$ & $\begin{array}{l}\text { high freq. } \\
<10 \mathrm{~h}\end{array}$ \\
\hline \multicolumn{6}{|l|}{$\overline{\mathrm{SW}}$} \\
\hline$u$ & 1.49 & 1.96 & 1.61 & 4.89 & 2.47 \\
\hline$t$ & 0.11 & 0.06 & 0.04 & 0.07 & 0.04 \\
\hline \multicolumn{6}{|l|}{$\mathrm{NE}$} \\
\hline$u$ & 2.34 & 1.40 & 0.56 & 3.54 & 1.60 \\
\hline$t$ & 0.18 & 0.12 & 0.03 & 0.09 & 0.06 \\
\hline
\end{tabular}

high-frequency $(<10 \mathrm{~h})$ variability. Greatest low-frequency variability was observed in the $v$ component at $\mathrm{NE}\left(8.6 \mathrm{~cm} \mathrm{~s}^{-1}\right)$, double that at $\mathrm{SW}$. In the synoptic band, larger standard deviations were found in the along-slope velocity between 2.5 and $5 \mathrm{~cm} \mathrm{~s}^{-1}$, again greater at NE. This trend was also observed in the temperature time-series. In the semi-diurnal band, the greatest measured standard deviation at SW was in the across-slope component, whilst at NE values were comparable in both $v$ and $u$.

Figure 7 shows variance preserving power spectra for $v$ and $u$ components of both current meters. A semidiurnal peak was apparent at both moorings, with a dominant $u$ component peak at SW, consistent with that summarised in Table 2. Reduced diurnal peaks were found at mooring NE relative to $\mathrm{SW}$. At periods greater than 1 day, the along-slope component dominated the spectral levels. Increased energy at 10-12-day periods was found, with a shift in the peak to lower frequency at SW (297 h compared to $256 \mathrm{~h}$ at NE). A band of higher energy between 4 and 6 days was found at NE, whilst at SW this was less apparent, apart from a single peak centred at 5 days, and not significant at the $90 \%$ level.
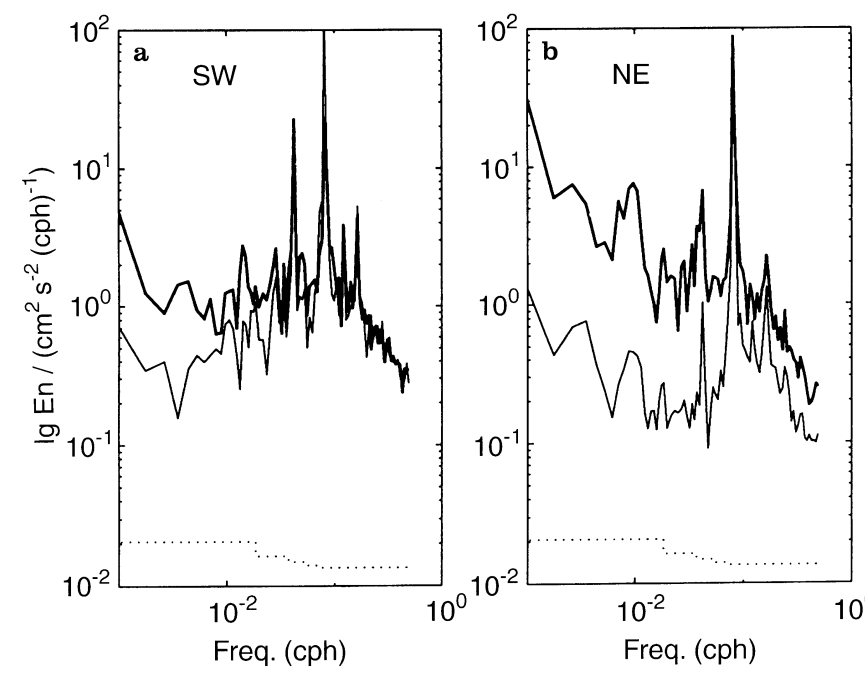

Fig. 7a, b. Variance preserving power spectra for a SW and b NE current meter. Thick lines are the along-slope velocity component and thin the across-slope velocity. The $90 \%$ upper confidence limit is shown by the dotted line
At SW higher energy was measured at intermediate periods between 1 and 4 days.

Figure 8 is a time-series of eastward and northward wind stress calculated from the data collected at the Irish Meterological Station at Belmullet (Fig. 1). Stress was estimated using the following relation:

$\tau=C_{D} \rho_{a} U|U|$

where $10^{3} C_{d}=0.63+0.066|U|$, and $\rho_{a}$ is the density of air (Saunders, 1977; Pingree and LeCann, 1990).

The mean stress for the year was $0.07 \mathrm{~Pa}$ in direction $43^{\circ}$ True, essentially parallel to the mean shelf-slope orientation at SW. The higher winter stresses continued until the end of April, the last period of sustained high stress measured just after the start of the current meter deployment. In the two weeks before the CTD transect was made, the wind stress was high, $0.19 \mathrm{~Pa}$ in direction $74^{\circ}$ True, giving downwelling favourable conditions on the shelf. This was perhaps reflected in the leakage of the bottom coastal water off shelf (Fig. 3). Spectra of the wind velocity components revealed no significant peaks with the exception of one at 7 days in the northward component. Time-lagged cross-correlations between the wind and current meter components were low, reaching maximum values of only 0.35 and 0.3 for the northward wind velocity and SW $v$ and $u$ components, respectively. The correlations peaked at a lag of 3-4 days, currents lagging the wind.

A tide gauge was installed at Ballyglass Pier, Co. Mayo, close to the site of the Irish Meterological Station. Unfortunately, data overlap between the gauge and the SW (closest) mooring was for the time when that mooring had been dragged. Correlations were sought, however, between the currents and temperatures at SW and the sea level at Ballyglass, after the measured levels were corrected for pressure variations. Figure 9 shows time-series of low-passed filtered (cut off $=2 \mathrm{cpd}$ ) corrected tidal height, temperature at SW and NE, together with a time-lag cross-correlation between the height and temperatures.

Variability between 2 and 5 days was observed in the tidal record, which was also apparent in the temperature time-series at SW, and essentially had components at 2.5 and 5 days. At NE, only the longer-period variation was found. There was a fair degree of coherence between the temperature time-series, for example, the sharp drop in temperature measured at SW on Julian Day 309, and 

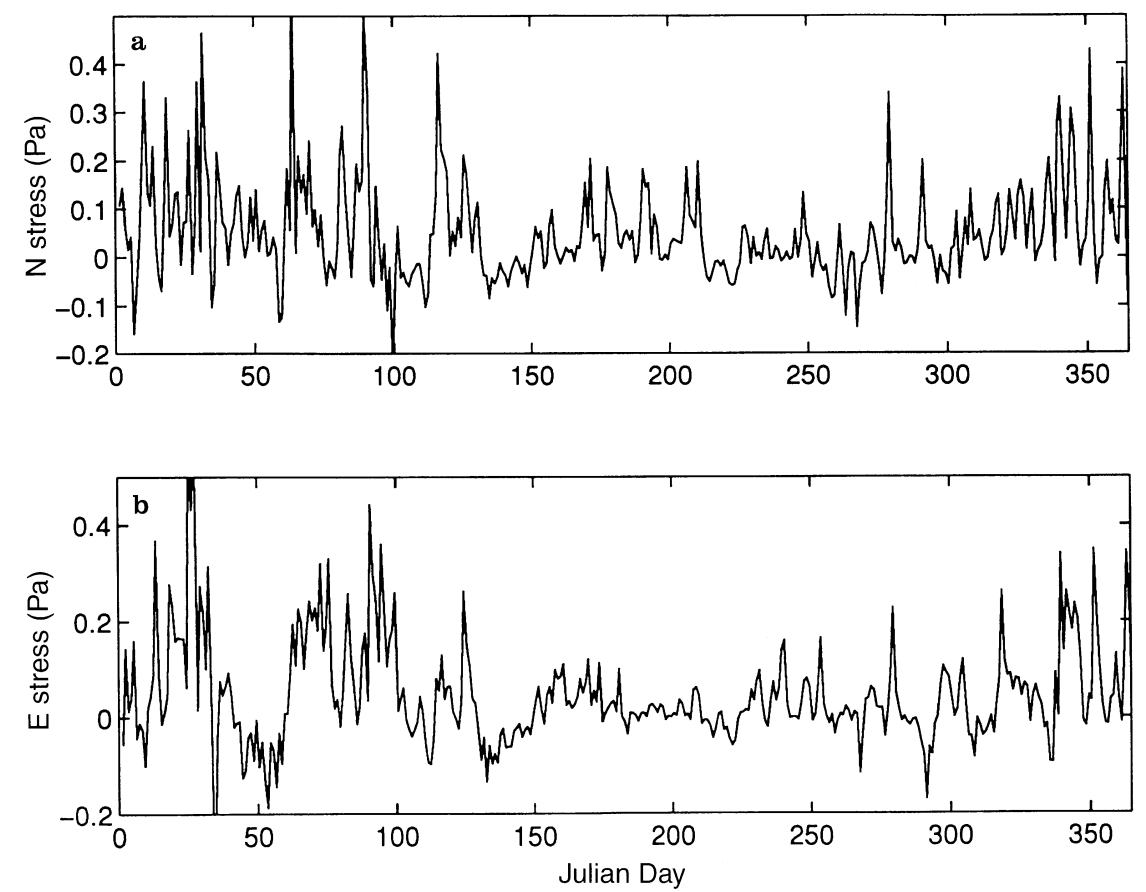

Fig. 8a, b. Time-series of a northerly and $\mathbf{b}$ easterly wind stress measured at the Irish Meterological Station at Belmullet $\left(54.228^{\circ} \mathrm{N}\right.$, $\left.10.007^{\circ} \mathrm{W}\right)$ observed at NE about $40 \mathrm{~h}$ later. The cross-correlations (Fig. 9c) showed a relatively high peak, $O(0.6)$, with peak correlation found between sea-level height and SW temperature when temperature led height by $6 \mathrm{~h}$. For
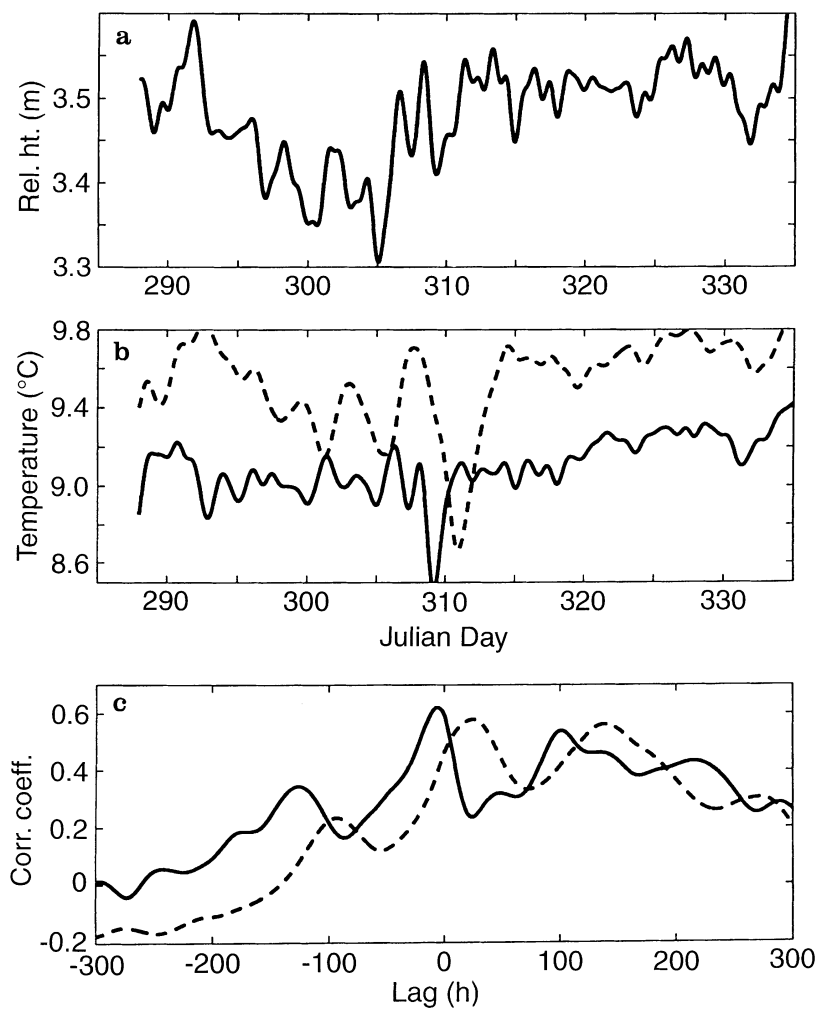

Fig. 9a-c. Time-series of 2-day low passed filtered a sea level (relative), and $\mathbf{b}$ temperature at SW (-) and NE (- - -). The time-lagged correlation coefficients between sea level and SW (-) and NE (- - ) temperatures are shown in $\mathbf{c}$ the NE temperature, peak correlation was found at temperature lagging sea-level height by $24 \mathrm{~h}$.

These phase differences, and also that found between the two temperature time-series $(40 \mathrm{~h}$, NE temperature lagging that at SW), can be related to possible shelf wave propagation in the region. Assuming the waves propagate in a direction of $40^{\circ}$, the mean orientation of the shelf, the phase lags represent the time for waves to travel along the shelf between mooring sites and the tide gauge. The time-lag of $6 \mathrm{~h}$ between the shelf region adjacent to $\mathrm{SW}$ and the tide gauge corresponds to a phase speed of about $C_{p}=60 \mathrm{~cm} \mathrm{~s}^{-1}$. A similar value is found for the distance between tide gauge and NE with a 24-h time-lag. The lag of $40 \mathrm{~h}$ between SW and NE temperatures, and the $72-\mathrm{km}$ mooring separation, gives $C_{p}=50 \mathrm{~cm} \mathrm{~s}^{-1}$.

\section{Discussion}

The observation of mean currents between 10 and $20 \mathrm{~cm} \mathrm{~s}^{-1}$ measured in the slope region south of the Malin Shelf falls between the lower values found to the south, e.g. $6 \mathrm{~cm} \mathrm{~s}^{-1}$ at $500-\mathrm{m}$ depth at the Goban Spur (Pingree and LeCann, 1989), $8-9 \mathrm{~cm} \mathrm{~s}^{-1}$ between 500 and $780 \mathrm{~m}$ on the Porcupine Bank slope (James, 1982), and the generally higher values found along the Hebrides slope, of $O(15-30) \mathrm{cm} \mathrm{s}^{-1}$ between $58^{\circ}$ and $59^{\circ} \mathrm{N}$ during CONSLEX (Huthnance, 1986). This is consistent with the idea of a general northward increase in mean slope current speed and transport. The mean value at mooring $\mathrm{NE}$ is, however, somewhat greater than the mean of $9 \mathrm{~cm} \mathrm{~s}^{-1}$ found further north $\left(57^{\circ} \mathrm{N}\right)$ at $490-\mathrm{m}$ depth in $1000 \mathrm{~m}$ of water (Booth and Ellett, 1983). The increase in mean current speed at NE is probably a reflection of the increased slope angle there 
and the fact that near-bottom currents are more influenced by topographic steering. The current meter at NE was located only $40 \mathrm{~m}$ above the seabed, whilst the $9-\mathrm{cm} \mathrm{s}^{-1}$ mean found by Booth and Ellett was measured at mid-depth. An increase in current would be expected where isobaths converge close to NE. Evidence for this has been found in results from a slope current model of the NE Atlantic (R. Pingree, personal communication) and from the track of a buoy drouged at $45 \mathrm{~m}$ which travelled north along the Irish Shelf, close to the 200-m isobath, and then sped up as it found the slope current in the region where the isobaths merged (Pingree et al., 1996).

The measurements indicate a polewards flowing slope current at a position located between previous observation sites west of the Porcupine Bank and the Malin Shelf to the north, where mean poleward flow has also been found. Continuity in the slope current along the NE Atlantic margin, however, has not been established. In the Rockall Trough, to the north of the Porcupine Bank, an anticyclonic eddy has been observed on several occasions (e.g. Booth and Meldrum, 1987). Whether this eddy is located at a break in the slope current in this region is not clear. An eddy at that location, however, might well produce some of the low-frequency variability in the current measured in this study, through interaction of the eddy motion with the slope current. Rotation periods of between 4 and 11 days found from the buoy tracks of Booth and Meldrum (1987) are comparable to the time-scale for longer-period variability found in the current time-series.

The CTD transect in Fig. 3 indicated the presence of a warm, saline core in the upper $300 \mathrm{~m}$ at the shelf edge, similar to that found further north by Hill and Mitchelson-Jacob (1993) and Booth and Ellett (1983) across the Malin and Hebrides Shelves. As in those transects, mixing of the saline core across the shelf edge was observed in spring. In this case, mixing occurred under strong winds favourable for surface Ekman flow onto the shelf with a related downwelling of deeper coastal water off shelf. Off-shelf near-bottom flow on the Malin Shelf has been reported by Shapiro and Hill (1997). For that case, however, the forcing mechanism was cascading of dense, saline water downslope, and not due to Ekman dynamics, as is the likely case here. Current measurements were made at a level below this core, close to the seabed, and a mean off-slope current was observed. Off-slope mean flow is a feature of other current measurements made along the NE Atlantic slope region. For example, Thorpe (1987) and Thorpe et al. (1991) report mean off-slope currents close to the seabed along the Porcupine Bank and Hebrides slope, due to Ekman downwelling in the bottom frictional layer beneath the mean polewards-directed slope current.

Wind stress may play a role in the low-frequency variability through the generation of shelf waves. The mean wind direction is essentially parallel to the orientation of the shelf edge at SW, but less so for the shelf edge further north at NE. Conditions are most effective, therefore, for the generation of shelf waves close to SW (Huthnance, 1992). The barotropic, or
Kelvin wave mode, has a phase velocity $\left(c_{p}\right)$ of $O(10) \mathrm{m} \mathrm{s}^{-1}$. Phase velocities decrease with increasing mode, higher modes having smaller phase speeds of $O(1) \mathrm{m} \mathrm{s}^{-1}$, with more nodes and greater amplitude over the slope region. Interaction of higher-mode waves with the SEC, through modulation of the saline core up/ down slope, would give rise to the changes in the currents and temperatures noted in Fig. 6. The estimated phase velocity of $0.5 \mathrm{~m} \mathrm{~s}^{-1}$ found here would be consistent with a higher-mode wave.

The fact that large-amplitude fluctuations in current are measured quite close to the seabed $(40 \mathrm{~m})$ might suggest that some bottom trapping of the motion might be occurring. Bottom-trapped waves have been studied by Rhines (1970) and occur for wave frequencies $\sigma<f$. The characteristic frequency for a bottom-trapped wave (propagating along slope) is $\sigma=N \alpha$, where $\alpha$ is the bottom slope. At SW, where $\alpha=0.07$ and Fig. 3 suggests $N=6 \times 10^{-4} \mathrm{~s}^{-1}$, the resonant wave period $\tau=1.8$ days, comparable to the period of variability measured at SW (Figs. 7 and 9). A large diurnal peak was found at SW from spectral analysis, perhaps reflecting some correspondence between resonance and the diurnal period.

Figure 10 plots the standard deviations of currents and temperatures in a 45.5-day block from the data filtered in the $20-30-h$ period range from Table 2 (45.5 days corresponds to a $1 / 4$ of the record at $\mathrm{SW}$ and a $1 / 5$ of the NE record), giving a rough indication of the variation of current/temperature amplitude in that frequency band throughout the observation period. For temperature, an increase in amplitude was found
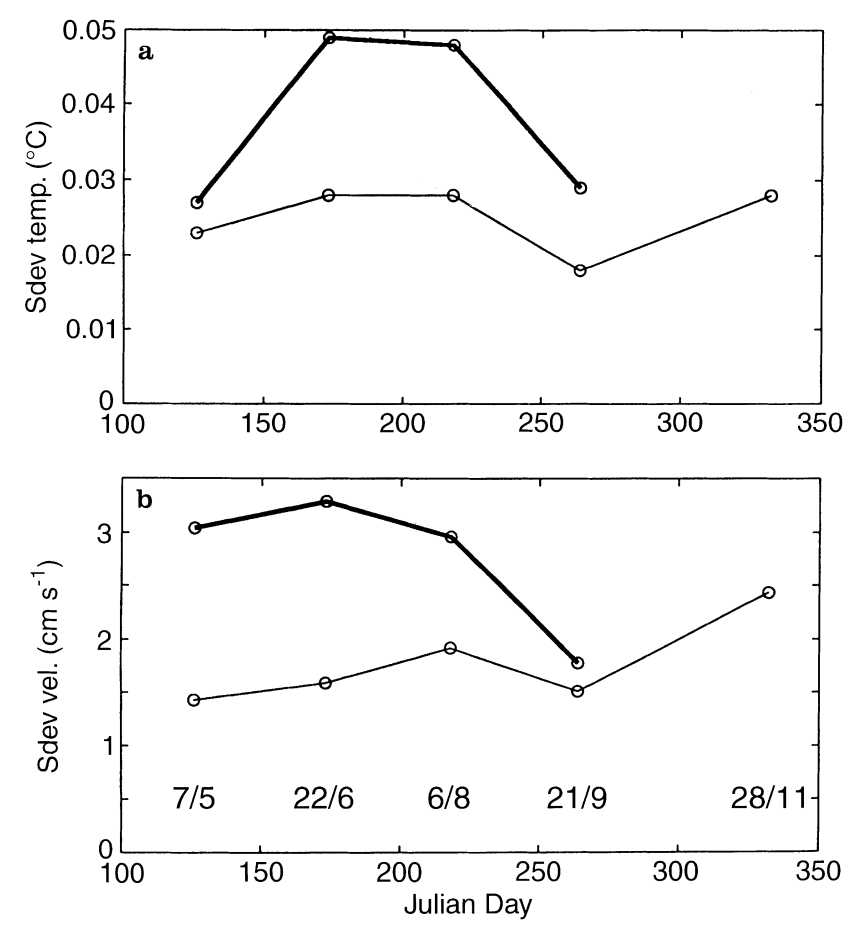

Fig. 10a, b. Standard deviation time-series of a temperature and b current speed measured in 45.5-day blocks from the 20-30-h filtered data at SW (thick) and NE (thin) lines 
during the early summer at SW, with a decrease in September. One possibility is that at $\mathrm{SW}$, matching for a bottom-trapped wave occurred as summer stratification increased, reducing the characteristic wave period from $O(2$ days) to $O(1$ day). Little variation was measured at $\mathrm{NE}$, however, but we would expect little amplification of the bottom diurnal signal as the bottom slope is twice that at SW reducing the wave frequency to something approaching the inertial frequency. It must also be noted that, without measurements higher in the water column, these ideas cannot be tested fully. Trapped diurnal waves on the Porcupine and Rockall Banks has been demonstrated in the numerical model of Pingree and Griffiths (1984). They note that, because of the difference in $\mathrm{O}_{1}$ and $\mathrm{K}_{1}$ wavelengths, the spring-neap signal (of period $328 \mathrm{~h}$ ) of the trapped waves propagates in the opposite direction to the phase velocity. Some of the variability of period 11-13 days (Fig. 6) may be a result of a spring-neap interaction with the SEC.

\section{Summary}

Measurements of the shelf-edge current on the continental slope north-west of Ireland between April and December 1994 have revealed a persistent poleward current close to the seabed. Above the measured current a warm saline core of water was located at the shelf edge, similar to that previously measured along the Malin and Hebrides slopes. These observations of the slope current are consistent with that measured along the slope both to the north and south of the study region and partly fill a gap in previous observations. Surface temperature and salinity observations also show that the upper portion of the SEC in the Porcupine Sea Bight region can be topographically steered across the deeper part of the Irish Shelf to the east of the Porcupine Bank.

Variability at sub-tidal periods between $2-5$ and 10 12 days was apparent. The 2-5-day-period motion was probably a result of the interaction of shelf waves with the SEC, with a strong correlation found between temperatures and sea level at a nearby coastal station. There was also a suggestion of bottom-trapped diurnal resonant wave motion at one mooring.

Acknowledgements. The authors wish to thank Mr. P. O'Malley for the use of his trawler 'An Capall Bán', and the expertise and assistance of himself, Tom Furey and Tom Creaven with the mooring construction and deployment. We are also very grateful to members of the SEFOS project from IfM, Hamburg, and the Master and crew of the FS Valdivia for invaluable seatime and assistance with mooring recovery. Financial assistance was provided by the EU through contract MAS2-CT93-0069, the Ocean Margin EXchange (OMEX) project.

Topical Editor D. Webb thanks J. M. Huthnance and J. Bartsch for their help in evaluating this paper.

\section{References}

Booth, D. A., and D. J. Ellett, The Scottish continental slope current, Cont. Shelf Res., 2, 127-146, 1983.

Booth, D. A., and D. T. Meldrum, Drifting buoys in the northeast Atlantic, J. Cons. int. Explor. Mer, 43, 261-267, 1987.

Ellett, D. J., and J. H. A. Martin, The physical and chemical oceanography of the Rockall Channel, Deep Sea Res., 20, 585$625,1973$.

Harvey, J., $\theta-S$ relationships and watermasses in the eastern north Atlantic, Deep Sea Res., 8, 1021-1033, 1982.

Hill, A. E., and E. G. Mitchelson-Jacob, Observations of a poleward-flowing saline core on the continental slope west of Scotland, Deep Sea Res., 40, 1521-1527, 1993.

Huang, W. G., A. P. Cracknell, R. A. Vaughan, and P. A. Davies, A satellite and field view of the Irish Shelf Front, Cont. Shelf Res., 11, 543-562, 1991.

Huthnance, J. M., The Rockall slope current and shelf-edge processes, Proc. R. Soc. Edinburgh, 88B, 83-101, 1986.

Huthnance, J. M., Extensive slope currents and the ocean-shelf boundary, Prog. Oceanogr., 29, 161-196, 1992.

Huthnance, J. M., Circulation, exchange and water masses at the ocean margin: the role of physical processes at the shelf edge, Prog. Oceanogr., 35, 353-431, 1995.

Huthnance, J. M., and W. J. Gould, On the northeast Atlantic slope current, in: Poleward flows along eastern ocean boundaries, Ed. S. J. Neshyba et al., Coastal and Estuarine Studies, 34, pp. 7681, 1989.

James, I. D., Tidal currents at two deep-sea moorings near the shelf edge, Deep Sea Res., 29, 1099-1111, 1992.

McMahon, T., R. Raine, O. Titov, and S. Boychuk, Some oceanographic features of northeastern Atlantic waters west of Ireland, ICES J. Mar. Sci., 52, 221-232, 1995.

Pingree, R. D., and D. K. Griffiths, Trapped diurnal waves on Porcupine and Rockall Banks, J. Mar. Biol. Ass. UK, 64, 889897, 1984.

Pingree, R. D., and B. LeCann, Celtic and Armorican slope and shelf residual currents, Prog. Oceanogr., 23, 303-338, 1989.

Pingree, R. D. and B. LeCann, Structure, strength and seasonality of the slope currents in the Bay of Biscay region, J. Mar. Biol. Ass. UK, 70, 857-885, 1990

Pingree, R. D., B. Sinha, and C. Griffiths, Seasonality of the slope currents in the Goban Spur region and implications for oceanslope-shelf exchange, Ocean Margin Exchange Final Report, B121-188, 1996.

Pollard, R. T., M. J. Griffiths, S. A. Cunningham, J. F. Read, F. F. Perez, and A. F. Rios, Vivaldi 1991 - a study of the formation, circulation and ventilation of eastern north Atlantic Water, Prog. Oceanogr., 37, 167-192, 1996.

Rhines, P., Edge-, bottom-, and Rossby waves in a rotating stratified fluid, Geophys. Fluid Dyn., 1, 273-873, 1970.

Saunders, P. M., Wind stress of the ocean over the eastern continental shelf of North America, J. Phys. Oceanogr., 7, 555$566,1977$.

Shapiro, G. I., and A. E. Hill, Dynamics of dense water cascades at the shelf edge, J. Phys. Oceanogr., (in press), 1997.

Thorpe, S. A., Current and temperature variability on the continental slope, Phil. Trans. R. Soc. London, A323, 471-517, 1987.

Thorpe, S. A., P. Hall, and M. White, The variability of mixing at the continental slope, Phil. Trans. R. Soc. London, A331, 183194, 1991 . 